\title{
The role of calcareous nannofossils in building age models for Cenozoic marine sediments: a review
}

\author{
Isabella Raffi ${ }^{1}$ D . Jan Backman² \\ Received: 29 August 2021 / Accepted: 9 January 2022 / Published online: 17 February 2022 \\ (c) The Author(s) 2022
}

\begin{abstract}
This review paper has been thought to emphasize the role of Biostratigraphy in Geosciences and, specifically, of calcareous nannofossils as dating tool. This group of calcareous plankton occurs in Mesozoic and Cenozoic carbonate-bearing marine sediments in all depositional settings and is routinely used for stratigraphic purposes. The importance of calcareous nannofossils in relative dating of marine sediments is due to their abundance, taxonomic diversity, rapid evolution and wide distribution in marine environments. Nannofossil biostratigraphy improved over the last few decades due to the use of accurate methods for data gathering, including acquisition of semiquantitative census data on high-resolution samples. These microfossils contribute to obtain reliable biostratigraphic classification in various time-intervals in the last $66 \mathrm{~m}$.y. and often provide the key to the interpretation of other stratigraphic records. Nannofossil biohorizons can be used as control points for constructing cyclostratigraphic composite sections, and for identification of magnetostratigraphic intervals, and have provided a basis for age models subsequently developed into orbitally tuned cyclostratigraphies or used for chronological revision of polarity timescale.
\end{abstract}

Isabella Raffi is honoured for having received the International Prize «Prof. Luigi Tartufari» 2020 for Geosciences by Accademia Nazionale dei Lincei in Rome.

Isabella Raffi

isabella.raffi@unich.it

Jan Backman

backman@geo.su.se

1 Dipartimento di Ingegneria e Geologia, Università "G.

d'Annunzio" di Chieti-Pescara, Chieti, Italy

2 Department of Geological Sciences, Stockholm University, Stockholm, Sweden 


\section{Graphic abstract}

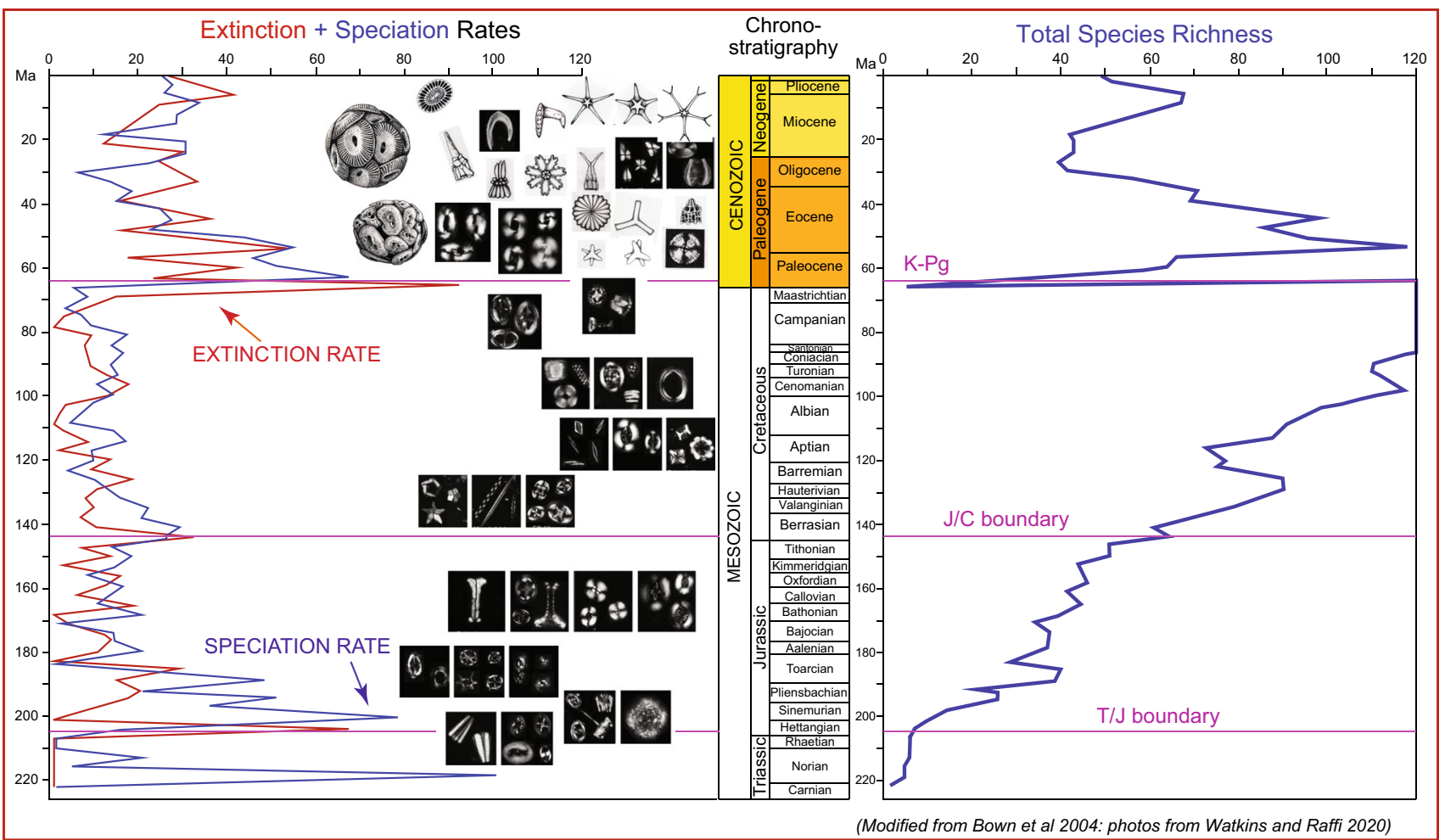

CALCAREOUS NANNOFOSSILS THROUGH TIME

Keywords Calcareous nannofossils $\cdot$ Biostratigraphy $\cdot$ Biochronology $\cdot$ Age models

\section{Introduction}

"Despite advances in magnetostratigraphy, stable isotope stratigraphy and various manifestations of cyclostratigraphy, it is still true that biostratigraphy is the essential tool by which the geological evidence for environmental change is put into a temporal framework."

\section{N.J. Shackleton (1995). ${ }^{1}$}

Over four billion years of Earth history is portrayed by the Geologic Time Scale (GTS), which synthesizes the many various means available to provide age of geological strata, the latest effort being that of Gradstein et al. (2020). Radioisotopic dating is a key method in this effort, in providing absolute ages that are based on radioactive decay of unstable atoms in geological materials throughout Earth's long history.

\footnotetext{
${ }^{1}$ From p. 517 in Shackleton et al. (1995).
}

During the youngest ca. $0.01 \%$ of Earth's history (the past 66 million years, the Cenozoic), which is the interest of our study as this refers to our experience, radioisotopic dating provides necessary absolute age tie points for seafloor marine magnetic anomaly boundaries, a crucial component for subdivision of Cenozoic time (Hiertzler et al. 1968; Cande and Kent 1992). Throughout the past 3 decades, absolute age determinations derived through astronomical tuning of Cenozoic sediments have grown in importance (Westerhold et al. 2020), based on cyclic behaviour driven by climate caused by the periodicity of celestial objects and expressed, for example, by oxygen isotopes and lithostratigraphic properties (Emiliani 1966; Hays et al. 1976; Hilgen 1991a).

Among geosciences, Stratigraphy (layer description) is the science of rock strata, their composition, distribution, succession and age relations. In our experience, there is a set of tools in the Cenozoic marine stratigraphy "toolbox" that stands out: biostratigraphy, paleomagnetic stratigraphy, stable isotope stratigraphy and various other cyclostratigraphies. 
Biostratigraphy employs paleontological methods, referring to the irreversible continuum of organic evolution as preserved in the fossil record which contributes to arrange rock units into relative order and to correlate them over geographic distance. Marine microfossil shells of Protista, as a result of their diverse and rapid evolution, are widely used for relative dating of marine sedimentary sequences through their biostratigraphic content. Marine calcareous plankton predominantly involves planktonic foraminifera and calcareous nannofossils that represent two key groups for providing biostratigraphic classification of carbonate-bearing Cenozoic rocks/sediments, both those cropping out on land and those recovered by coring of marine sediments and scientific ocean drilling.

This review paper deals with calcareous nannofossils and aims to illustrate their quality as biostratigraphic and biochronologic tools and their role in the construction of age models of Cenozoic marine sedimentary sequences. The intent is also to emphasize how calcareous nannofossil biostratigraphy contributes to the Geologic Time Scale, in providing guidance for identification of cycle numbers and magnetic polarity intervals.

\section{About calcareous nannofossils}

Calcareous nannofossils refer to coccolithophores, a group of single-celled algae (haptophyte protists) belonging to the phytoplankton that produce calcareous elements through biomineralization. These microfossils were first described back in the mid-nineteenth century when the terms 'coccoliths' 'coccosphere' were introduced (Huxley 1868; Wallich 1861). This group includes also morphogroups with uncertain biological affinity, but their small size $(1-40 \mu \mathrm{m})$, composition (low magnesium calcite), abundance and distribution in marine environments make it reasonable to assume that these morphogroups were coccolithophores. See Young et al. (1997) for coccolith and calcareous nannofossil terminology.

The importance of calcareous nannofossils in relative dating of marine sediments is due to their abundance (millions of specimens per gram carbonate-bearing sediment), taxonomic diversity, rapid evolution, wide distribution in marine environments and preservation potential (slightly less susceptible to dissolution than planktonic foraminifers).

Calcareous nannofossils occur in Mesozoic and Cenozoic carbonate-bearing marine sediments in all depositional settings that are not covered by sea-ice. Despite the small size of these fossils, their abundance, distinct morphology and optical behaviour facilitate the recognition of species using standard polarizing light microscopy. The history of calcareous nannofossils began with their initial radiation during the Late Triassic (Norian Age) at ca. $220 \mathrm{Ma}$ (von Salis
1998; Bown 1998). Widespread adaptive radiation and species turnovers followed for about 154 million years in the Mesozoic Era, ending with the catastrophic extinction at the Cretaceous-Paleogene (K-Pg) boundary at $66 \mathrm{Ma}$ when, in the oceans, ca. $75 \%$ of species and ca. $40 \%$ of genera became extinct (Sepkoski 1996), including calcareous plankton (Schulte et al. 2010, and references therein). Although over $90 \%$ of latest Cretaceous calcareous nannofossils species disappeared during the K-Pg boundary mass extinction (Bown et al. 2004), a rapid adaptive radiation followed during the early Paleocene, when species richness and establishment of new orders and families increased (Perch-Nielsen 1985). Evolutionary changes continued with variable intensity through the Cenozoic Era, resulting in numerous appearance and extinction events (biohorizons) which thus provided a rich set of biohorizons available for biostratigraphy.

A few words about taxonomy. We confess to being "lumpers" rather than "splitters". This means that our taxonomic concepts permit some intra-specific morphologic variability rather than describing a "new" species for a morphology that deviates only marginally from the original description of the species. The question about how to define the morphological limits of a morphospecies remains a relatively poorly investigated and ditto understood character among marine microplankton shells (including those of calcareous nannofossils), which typically are described qualitatively rather than being based on detailed morphometrics. However, errors in taxonomy are probably distributed both among lumper and splitter micropaleontologists and when it comes to key Cenozoic biohorizons, taxonomic problems based on morphospecies concepts exist but are considered to be few.

\section{Early efforts to employ calcareous nannofossils in biostratigraphy}

Efforts to organize calcareous nannofossils into their proper (bio-)stratigraphic order began less than 70 years ago: Bramlette and Riedel (1954), Stradner (1959) and Bramlette and Sullivan (1961) pioneered the earliest investigations about Cenozoic calcareous nannofossil biostratigraphy, whereas Stradner (1961) pioneered biostratigraphic work among Jurassic and Cretaceous calcareous nannofossils. The focus of this paper is on the Cenozoic, in harmony with our expertise.

In less than 2 decades after Bramlette's pioneering work, two independent and subsequently widely used Cenozoic calcareous nannofossil biostratigraphic schemes were established (Martini 1971; Bukry 1973): the former mainly used marine sections exposed on land, often at middle latitude settings, whereas the latter relied on low-latitude sediment successions, retrieved by the Deep Sea Drilling Project (DSDP) a mere five years after its start. During the late 
60ies and 70ies several other biozonations were established for various parts of the Cenozoic, some of which aimed for specific regions (Bramlette and Wilcoxon 1967; Hay et al. 1967; Ellis 1979; Raffi and Rio 1979). About 40 years after Martini's and Bukry's biozonations, we were involved with two revised calcareous nannofossil zonations, one for the Neogene and Quaternary (Backman et al. 2012) and the other for the Paleogene (Agnini et al. 2014), both taking into account improvements made during these 4 decades with a focus on the reliability and applicability of individual biohorizons.

\section{Calibration of calcareous nannofossil biohorizons to independent time scales}

There are a few main strategies at hand to convert evolutionary appearances or extinctions of marine plankton taxa onto an accurate geologic timeline. First, providing age estimates of calcareous nannofossils from numerous deep-sea sediment sequences via direct radioisotopic measurements is a difficult task. Reasons involve analytical costs and, more importantly, the rare presence of radioactive elements and their decay products in most marine pelagic sediments, except for the interval corresponding to the most recent $0.0008 \%$ of Cenozoic history, which can be organized in terms of time by carbon-14 dating. Hence other means are needed to progress.

Two key tools emerged during a formative decade that helped convert, or calibrate, positions of biohorizons in marine sediment sequences into age estimates: (1) the development of the Geomagnetic Polarity Time Scale (GPTS) and (2) cyclostratigraphy. The first portrays the polarity sequence as derived from marine magnetic anomaly analysis combined with selected radiometric age tie points, and the latter portrays the astronomically forced paleoclimatic change as preserved in the sediment stratigraphy, a strategy also known as astrochronology. Two of the most commonly applied tools in astrochronology are stable isotopes of carbon and oxygen (in essence geochemistry) and lithologic properties (in essence geology, that is, biological, chemical and physical properties of marine sediments).

\subsection{The GPTS and Cenozoic calcareous nannofossil calibrations}

Soon after geophysical measurements began to establish the occurrence of alternating switches between normal and reversed remanent magnetizations among stratigraphically layered volcanic rocks on land (Cox et al. 1963), the corresponding "geomagnetic polarity reversals" were observed to be preserved also in deep-sea sediment cores. This was a major eye-opener indicating that any given polarity reversal in a deep-sea sediment core should represent a globally synchronous single point in geologic time. It follows that a potential tool to hinge biostratigraphic data onto magnetostratigraphic polarity records was discovered, the first published by Harrison and Funnell (1964), soon followed by Opdyke et al. (1966). Their work was followed by numerous other similar studies (e.g., Saito et al. 1975) over just a decade after the initial pioneering efforts, which genuinely improved age determinations of marine biohorizons. Moreover, during that decade of geoscientific development, Heirtzler et al. (1968) published the first marine magnetic anomaly time scale, or GPTS, that encompassed the entire Cenozoic. Amazingly, this first Cenozoic GPTS from 1968 was based on only two age tie points: spreading center at $0.00 \mathrm{Ma}$ and base of the polarity Chron C2An.1n (base Gauss), at the time $3.35 \mathrm{Ma}$, and was linearly extrapolated to nearly $80 \mathrm{Ma}$, into the Late Cretaceous. In retrospect, Heirtzler's GPTS remains surprisingly close to present data.

A comprehensive synthesis of the early developments of marine magnetic anomaly time scales was provided by Ness et al. (1980). Not far after, Glen (1982) wrote his book "The Road to Jaramillo: Critical years of the Revolution in Earth Science", an inspiring historical piece about how the theory of plate tectonics emerged and got manifested among geoscientists as well as a much broader general audience. Magnetostratigraphy and, by implication, bio-magnetostratigraphy, are intertwined with this history.

The earliest effort to match marine plankton biostratigraphic data with a complete Cenozoic GPTS is that of Berggren (1969), depicting Heirtzler's GPTS, ${ }^{2}$ saying that "Palaeomagnetic reversals are plotted at their assumed age interval. The relationship of palaeomagnetic stratigraphy to the biostratigraphic zonation based upon planktonic foraminifera remains to be verified but is accurate down to about 5 million years on the basis of present data". Subsequently, Berggren et al. $(1985,1995)$ published two widely used Cenozoic time scales, using the evolving marine magnetic anomaly time scales for calibration with an abundance of new biostratigraphic data of planktonic foraminifera, calcareous nannofossils (and radiolaria in the 1985 opus), from deep-sea sediment cores retrieved by the DSDP and the Ocean Drilling Program (ODP).

Over the past 60 years bio-magnetostratigraphic data have been, and remain, a powerful tool in establishing Cenozoic age estimates of calcareous nannofossils in marine sediments (e.g., Backman and Shackleton 1983; Backman 1986; Olafsson 1991; Gartner 1992; Agnini et al. 2007). Once calibrated to magnetostratigraphy, biostratigraphic data are commonly and successfully applied to generate age models in marine

\footnotetext{
2 No reference given but Heirtzler's was the only GPTS available in 1969 that encompassed the entire Cenozoic.
} 
sediments lacking magnetostratigraphy (e.g., Kroenke et al. 1991; Curry et al. 1995). In contrast, interpreting magnetostratigraphic data without guidance from biostratigraphy may result in huge discrepancies: an example being the result from ODP Site 690 in which, at the identical level, biostratigraphy suggested an age of $57.8 \mathrm{Ma}$ whereas magnetostratigraphy suggested an age of $44.66 \mathrm{Ma}$, "constructed without recourse to biostratigraphic data" (Shipboard Scientific Party 1988).

A problem inherent in bio-magnetostratigraphic data, however, pertains to resolution. An individual age estimate of a biohorizon calibrated to magnetostratigraphy rarely falls precisely on a reversal boundary in continuously deposited sediments but is typically located within an interval of variable length/duration of either normal or reversed polarity. Standard procedure is to derive an age estimate of the biohorizon via linear interpolation between the two nearest reversal boundaries, often expressed in terms of percentage of time distance from the established age of nearest reversal boundary (Agnini et al. 2007, 2014). The age uncertainty of the biohorizon thus partly depends on the duration of the polarity zone, an uncertainty that can be several hundred thousand years if the sedimentation rate varies within a polarity zone of longer duration.

Cyclostratigraphy is the answer to this bio-magnetostratigraphic resolution problem because astronomical tuning of cyclic behaviour of some property (biological, chemical, physical) can accurately subdivide time into shorter aliquots within longer polarity zones.

\subsection{Cyclostratigraphy and calcareous nannofossils}

Below follows a brief historical account about the initial merging of cyclostratigraphy and calcareous nannofossil biochronology.

Harold Urey (1948) rightfully exclaimed to have found a "geological thermometer" when analysing isotopes of oxygen (see excellent review by Pearson 2012, on theory and use of foraminiferal oxygen isotopes). A few years after, Urey's student Cesare Emiliani began to publish his pioneering work $(1954,1955)$ about reconstructing ocean paleotemperatures by means of measurements of oxygen isotopes in marine benthic and planktonic foraminifers. In his Fig. 1 in the 1954 paper, Emiliani reported three (3) data points, assumed to show an $8{ }^{\circ} \mathrm{C}$ temperature cooling of abyssal waters from the Oligocene to the Pliocene (Fig. 1). A good figure to keep in mind, to use in teaching and to compare knowledge from the pioneering days with the development over the following 50 years-when thousands of similar data points were used to depict evolving paleoclimatic and paleoceanographic conditions (Zachos et al. 2001) (Fig. 2). Regardless, one of Emiliani's key colleagues in the field, N.J.

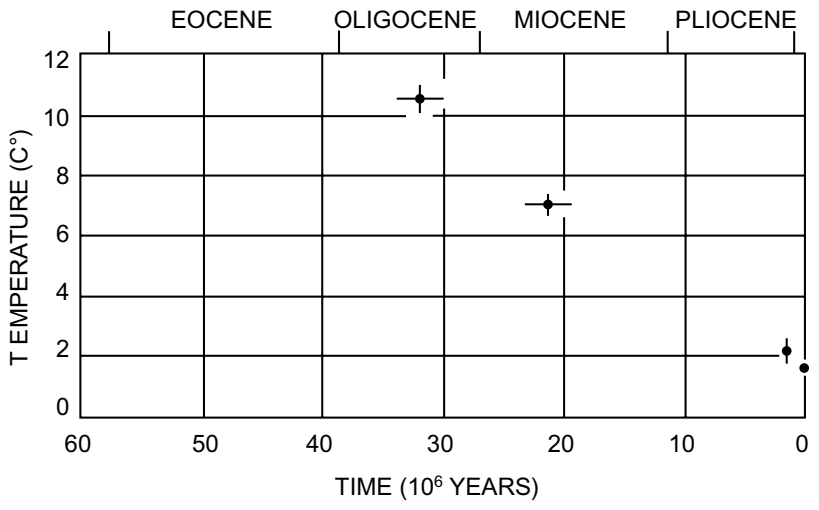

Fig. 1 Replication of Fig. 1 from Emiliani (1954) in which he reconstructed ocean paleotemperatures through measurements of oxygen isotopes in marine benthic and planktonic foraminifers

Shackleton, once remarked to us that Emiliani clearly was ten years ahead "of the rest of us".

In a synthesis paper on Pleistocene paleotemperatures, Emiliani (1966) noticed that "the correlation coefficient between the astronomically calculated ages of the summer insolation minima at $65^{\circ} \mathrm{N}$ and the stratigraphic position of the temperature minima in the 'average core' previously mentioned is 0.997", concluding that insolation variations drive the Pleistocene oscillations in climate. Three major advances followed: first, a year later, Shackleton (1967) established that oxygen isotopes represent both paleotemperature and global ice volume; second, ten years after Emiliani's synthesis paper, Hays et al. (1976) published a landmark paper on "Variations in the Earth's orbit: Pacemaker of the Ice Ages", which ended "four decades of controversy" of the Milankovitch model (Gribbin 1976) and opened the field of astrochronology. Third, in another landmark paper, Shackleton and Opdyke (1973) presented magnetostratigraphic and foraminiferal oxygen isotope data from a deepsea core (V28-238) raised from the Ontong-Java Plateau. They managed to subdivide the Brunhes (polarity Chron $\mathrm{C} 1 \mathrm{n}$ ) into 19 distinct oxygen isotope stages and, based on linear interpolation, listed age estimates for all 19 oxygen isotope stage boundaries. Oxygen isotope stages thus provided a tool to subdivide time in longer geomagnetic polarity zones, thus permitting improved resolution of age estimates of marine biohorizons.

The first such astro-biochronological work was published by Thierstein et al. (1977), a year after Hays et al. (1976), providing calibration of calcareous nannofossil biohorizons to oxygen isotope stratigraphies from several deep-sea piston cores. They also introduced a new concept in calcareous nannofossil biostratigraphy, based on a shift in relative abundance between two key taxa, of which one dominant species (in terms of relative abundance) was replaced by another dominant species: this kind of biohorizon was used 
Fig. 2 Comparison of data (A) from the pioneering Emiliani's publication (Fig. 1 in Emiliani 1954) with data (B) from deepsea core sediments (Zachos et al. 2001, modified), that depict the evolving paleoclimatic and paleoceanographic conditions in the Cenozoic
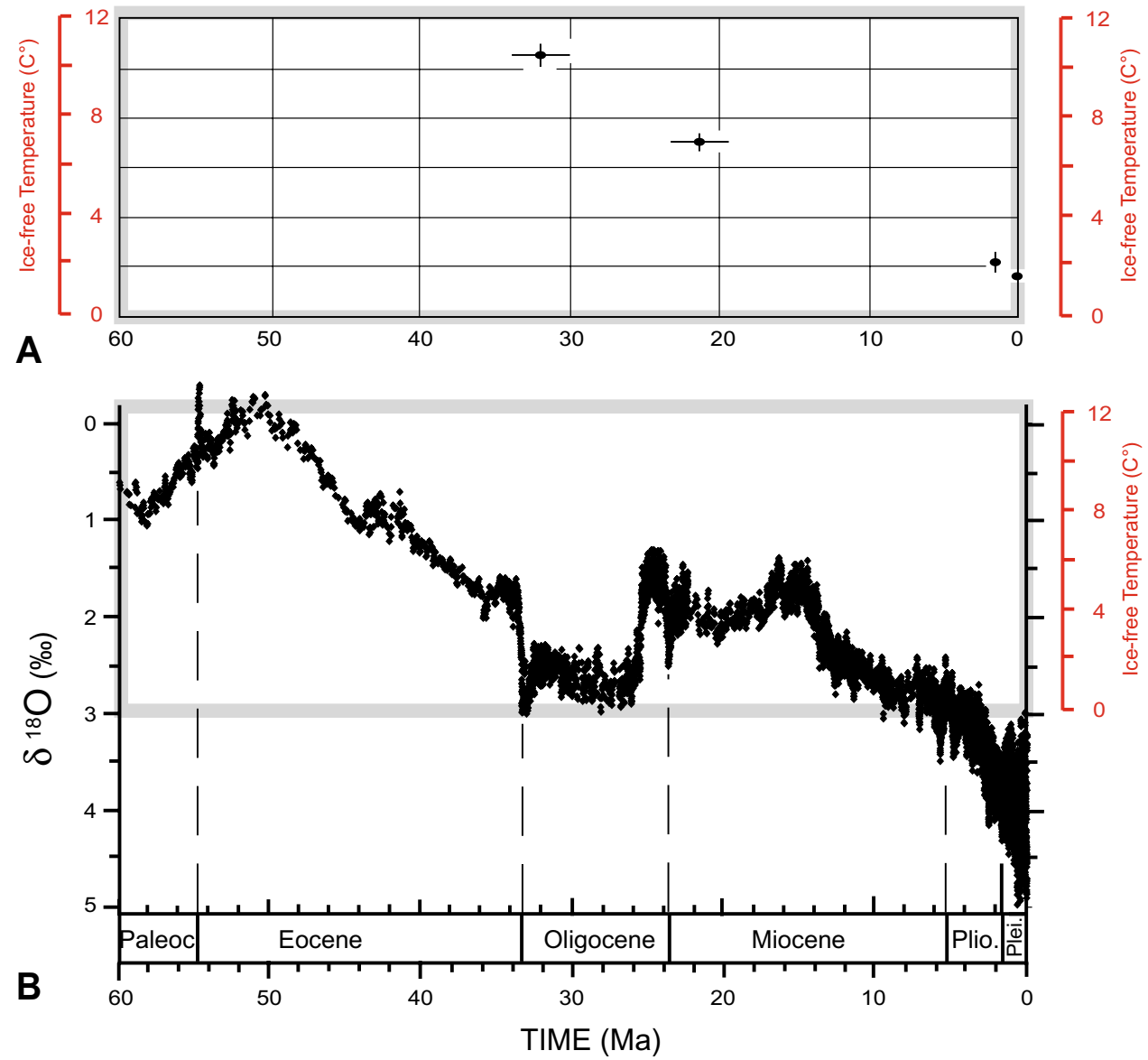

as biostratigraphic and biochronologic marker. For us, Thierstein et alii's paper became a source of much inspiration.

Different expressions of sedimentary rhythms have since long been observed in the geological record, for example fluctuating carbonate contents (Arrhenius 1952) and sapropels (Kidd et al. 1978). A series of studies began to emerge over a decade from the late 70ies to late 80ies, leading up to the pioneering work of Hilgen $(1987,1991 \mathrm{a})$ on the usefulness of rhythmical bedding in Mediterranean Plio-Pleistocene marine strata, uplifted and presently exposed on land, for improvements of the geologic time scale. Hilgen's work contributed to improve calcareous nannofossil biochronology (Hilgen 1991b) and provided a tool for comparison and correlation with corresponding open ocean biochronologies derived from astrochronology (e.g., Raymo et al. 1988; Shackleton et al. 1990).

During the 90ies we further developed Pleistocene through late Miocene calcareous nannofossil biochronology based on astrochronology (Raffi et al. 1993; Backman and Raffi 1997) and, subsequently, Raffi et al. (2006) synthesized calcareous nannofossil astrobiochronology over the past 25 million years. In this synthesis, biohorizons have been placed into the combined chronological framework of magnetostratigraphy and astrocyclostratigraphy, as exemplified in Fig. 3 (from Raffi et al. 2006).

In addition to its importance for the relative chronology of marine sediments, another relevant result derived from the improvement of nannofossil biostratigraphy has been the quality of the database acquired, in terms of accuracy and reliability (Rio et al. 1990; Raffi 1999). This is related to the approach of acquiring (semi) quantitative biostratigraphic data (see discussion in subchapter 4.3). The direct comparison of these detailed data with cyclic variation of other paleoenvironmental proxies (i.e., magnetic susceptibility, carbonate concentration, stable isotope ratios) led to new discoveries on the abundance behaviour of the species: a direct response by several nannofossil taxa, as Discoaster and Sphenolithus, to orbitally forced climatic variation was pointed out, as shown by fluctuations in abundances which are in the frequency range of earth orbital variations (e.g., Backman and Pestiaux 1987; Chepstow-Lusty et al 1989; Gibbs et al. 2004). An example from ODP Site 926 is shown in Fig. 4, showing cycles in the sediment cores and abundance of Discoaster kugleri plotted vs. magnetic susceptibility (darker areas $=$ higher susceptibility and vice versa). 


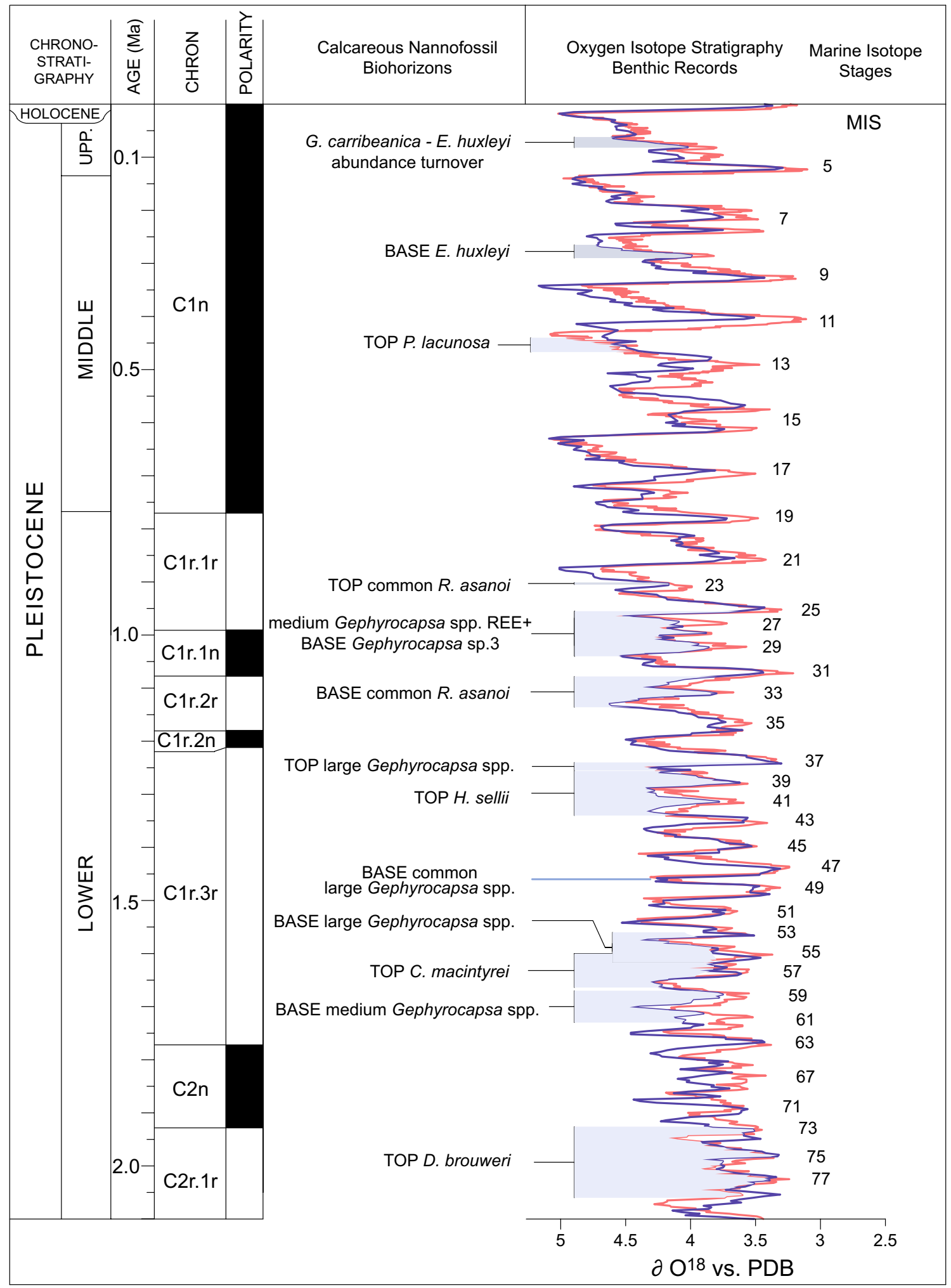

Fig. 3 Calcareous nannofossil biohorizons vs. framework of astronomically calibrated magnetic reversal records and stable isotope stratigraphies for the last 2.0 m.y. ( modified from Raffi et al. 2006) 


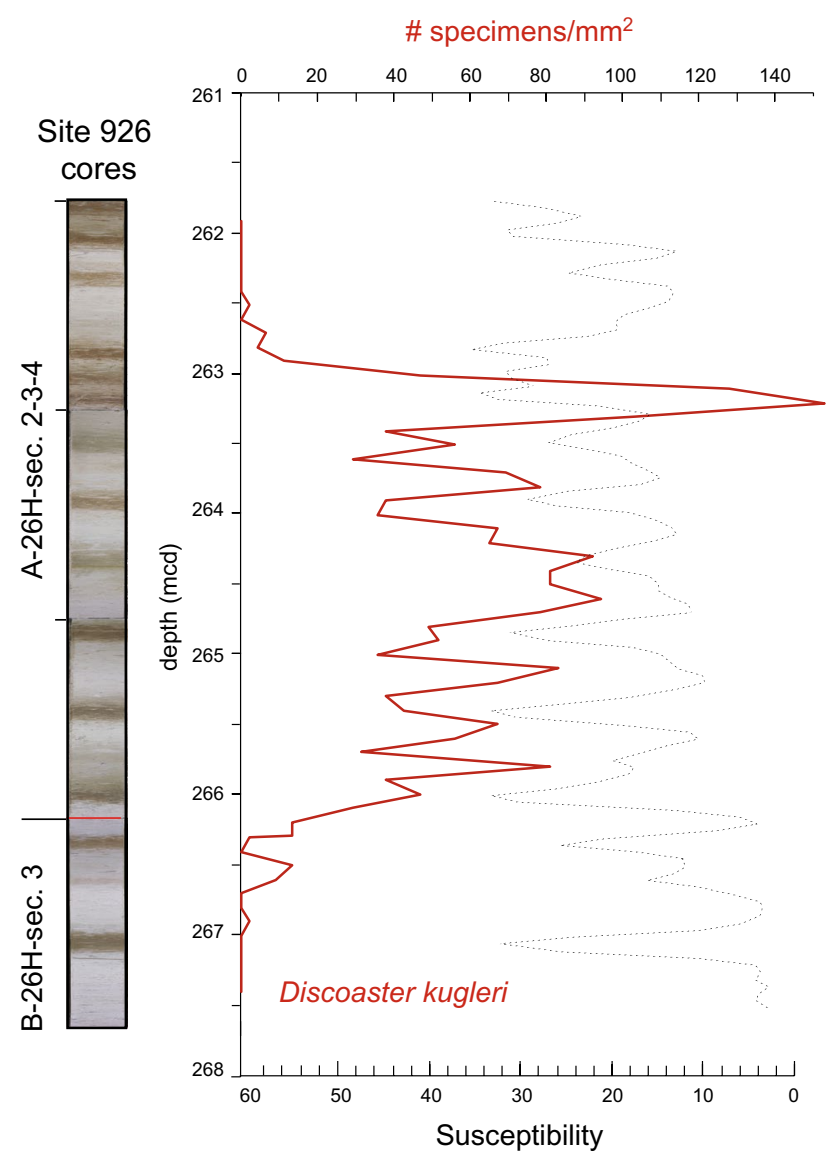

Fig. 4 Abundance record of Discoaster kugleri at ODP Site 926 sediment cores showing cycles (https://web.iodp.tamu.edu/janus web/imaging/photo.cgi). Abundance fluctuations are compared with magnetic susceptibility record, in which darker layers correspond to higher susceptibility/higher clay content and, vice versa, lighter layers to low susceptibility/higher carbonate content

\subsection{Calcareous nannofossil biostratigraphy: problems and solutions}

Biostratigraphic analyses using calcareous nannofossils commonly rely on the presence/absence data of species together with qualifiers such as "barren" "rare" "few" "common" "abundant", i.e., in range charts. We, and most other colleagues, have employed this method onboard during numerous DSDP/ODP/IODP expeditions. This method more or less represents a black box containing information that is virtually impossible to judge and evaluate independently by non-biostratigraphers, although most biostratigraphers provide information that can be reproduced by other experts in the field.

During several of these scientific ocean drilling expeditions, in biostratigraphic analyses we partly abandoned the range chart method, which is to list every species observed with one of the above qualifiers in each sample investigated. We applied the range chart method only to analyse core catcher samples, using much time to what we refer to as "biohorizon chasing". To put it simply, in delineating a biohorizon between two core-catcher samples, how could it be further constrained in terms of core depth via additional within-core samples? Chasing an appearance or extinction of a species in a $9.5 \mathrm{~m}$ long core is readily done if your smear-slide production line is quick, permitting at least ten smear-slides to be produced in an hour from raw samples. In shipboard analyses during ODP Leg 154, for example, we constrained most critical calcareous nannofossil biohorizons to within $40-80 \mathrm{~cm}$, collecting $12-14$ (or more) samples per core. This reduced depth uncertainties of most age indicative biohorizons, from the traditional $\pm 450 \mathrm{~cm}$ if using only core catcher samples, to $\pm 20-40 \mathrm{~cm}$; that is, $11-20$ times more precise depths of age tie points of the biohorizons (Fig. 5).

We have previously discussed the biostratigraphic resolution problem (Backman and Raffi 1997): "Several analytical fields in paleoceanography [...] routinely use sampling intervals that are close enough to capture the finest details of the records of environmental change that are preserved in cores. Marine biostratigraphic work, in contrast, has rarely adopted the smallest meaningful sampling interval to acquire its basic information about the evolutionary emergence or extinction of species." Thus, a problem of calcareous nannofossil biostratigraphy refers to resolution, which can only be solved by analysing additional samples, at similar sample frequency used for proxy records, so that depth positions of individual biohorizons are narrowed.

Another problem in biostratigraphy refers to the difficulty to independently evaluate the reliability of data, which preferably should be resolved using census data showing the abundance behaviour (relative or semiquantitative) of individual taxa. We have since long employed a semiquantitative approach (Backman and Shackleton, 1993) to solve this biostratigraphic "black box" problem. In fact, the use of the semiquantitative methodology overcomes the problem of subjectivity inherent in the 'qualitative' analytical approach based on the presence/absence method. Although the 'qualitative' approach can result in an accurate biostratigraphy, it relies on a combination of subjective judgements involving taxonomic identification and assessment of relative abundance (e.g., "rare", "common") and excludes types of information useful for enhanced biostratigraphic resolution. We use the label 'semiquantitative' in terms of representing an estimate of nannofossil census data that have less than quantitative precision, yet graphically manages to depict true abundance variability on the order of $\pm 10-15 \%$.

The resolution problem can be addressed as a precision problem: how precise can biostratigraphers determine positions of evolutionary appearances and extinctions in the stratigraphic column? And, how to determine the smallest meaningful sample interval for determinations of biohorizons? The abundance behaviour problem can be addressed 
Fig. 5 Effects of different sample resolution and data gathering. The stratigraphic range (lower part) of Discoaster broweri at ODP Site 926 is depicted at different sampling intervals with different abundance evaluation: (1) 5.0-m sampling interval (1 sample/400 k.y.); (2) 2.5-m sampling interval (1 sample/200 k.y.); (3) 0.1-m sampling intervals (1 sample/8 k.y.). Comparison of presence/absence data (1) to semiquantitative abundance data of the taxon ( 2 and $\mathbf{3})$ is shown. $\mathrm{C}=$ common specimens; $\mathrm{F}=$ few specimens; $\mathrm{R}=$ rare specimens. The plot showing high-resolution data (3) displays considerable details (short-term variations in abundance)

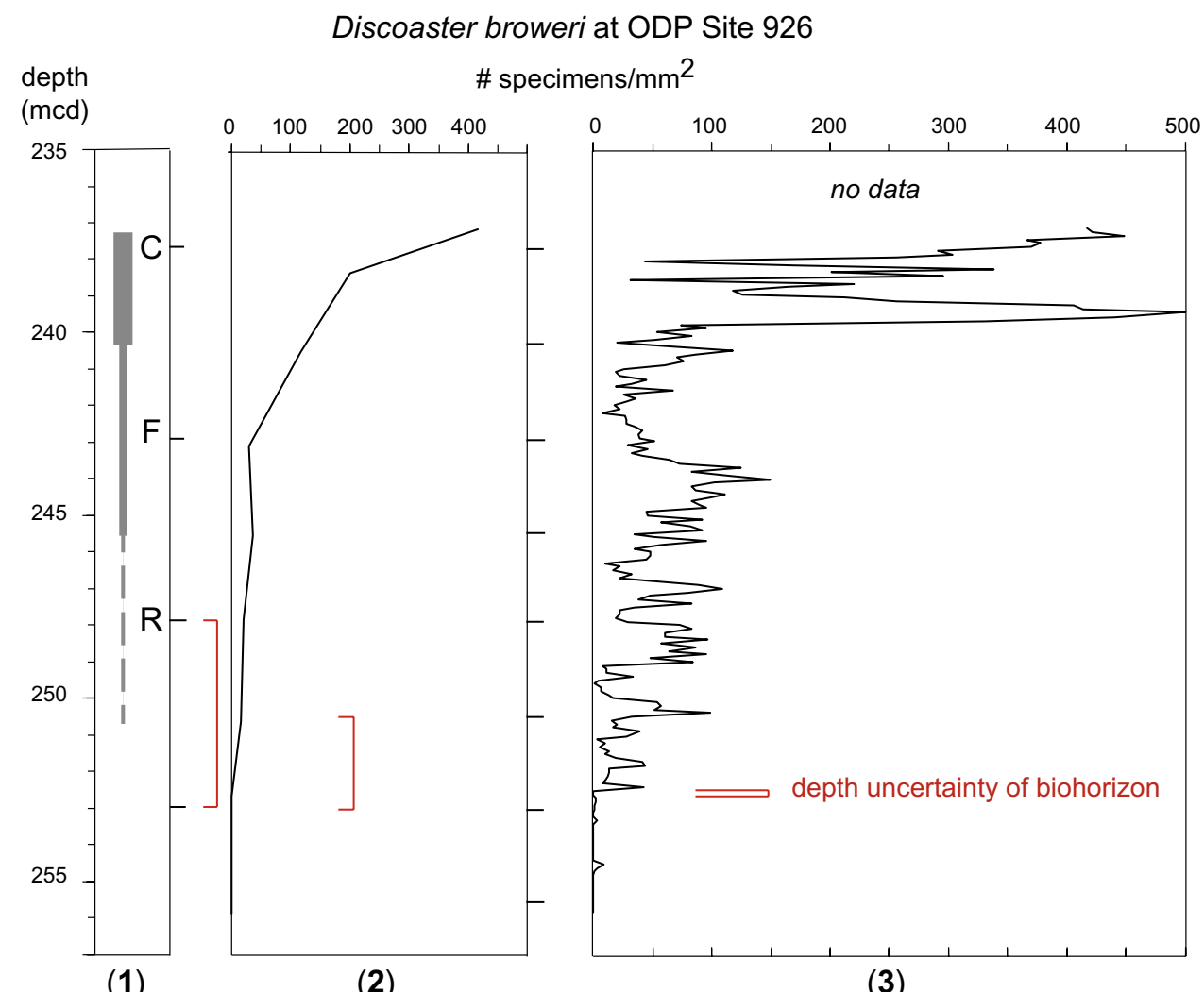

(1)

(2)
(3) as an accuracy problem: how accurate can we determine evolutionary appearances and extinctions in the stratigraphic column? Biostratigraphers often experience low and sporadic occurrences of critical taxa prior to evolutionary appearances or after extinctions. Again, the solution, which opens the "black box", lies in a combination of narrowing sample spacing intervals with semiquantitative analyses, permitting independent judgements.

\section{Precision of calcareous nannofossil biochronology for accurate correlation}

The precision of age estimates of individual calcareous nannofossil biohorizons has been steadily improved over several decades due to the use of semiquantitative analyses and decreasing sample-space intervals, in combination with calibration of individual biohorizons directly to magnetostratigraphy and astronomically tuned cyclostratigraphy. Concomitantly, the construction of the Cenozoic time scale has been an ongoing process through the past 4-5 decades in which calcareous nannofossils have played a role (see overviews in GTS2020 chapters by Raffi et al. 2020; Speijer et al. 2020). This multifaceted development has resulted in precise age determinations of numerous Cenozoic biohorizons, often within a few $10^{3}-10^{4}$ years. Below, a few examples serve to illustrate different uses of calcareous nannofossil data for correlation purposes and dating.

When sedimentary cycles are exposed in sedimentary sections outcropping on land, but no continuous succession could be logged and sampled along a single trajectory, or when ODP scientific drilling recovers sediment from multiple holes cored from single sites, the construction of composite sections is essential for building cyclostratigraphic records that could be correlated to astronomical target curves and calibrated for constructing age models. In the absence of magnetostratigraphic data, biostratigraphy provides necessary correlation: an example is shown in Fig. 6, in which composite depth sections from adjacent holes and site-bysite correlation of the same composite sections (Shipboard Scientific Party 1995) depend on precise biostratigraphic data, given the lack of reliable magnetostratigraphic records in those sediment cores.

Likewise, the synchroneity of calcareous nannofossil biohorizons can be relevant for discussing the validity of timescales. In Fig. 7, it is shown that the nannofossil biostratigraphic data, obtained in two sedimentary sections with rhythmic bedding, are in line, although the two cyclostratigraphic records are from different geographic areas and latitudes, one in the Mediterranean (Monte Gibliscemi, Sicily; Hilgen et al. 2000), the other in the tropical Atlantic Ocean (Ceara Rise; Backman and Raffi 1997). Most importantly, the estimated astronomical ages for the biohorizons agree 


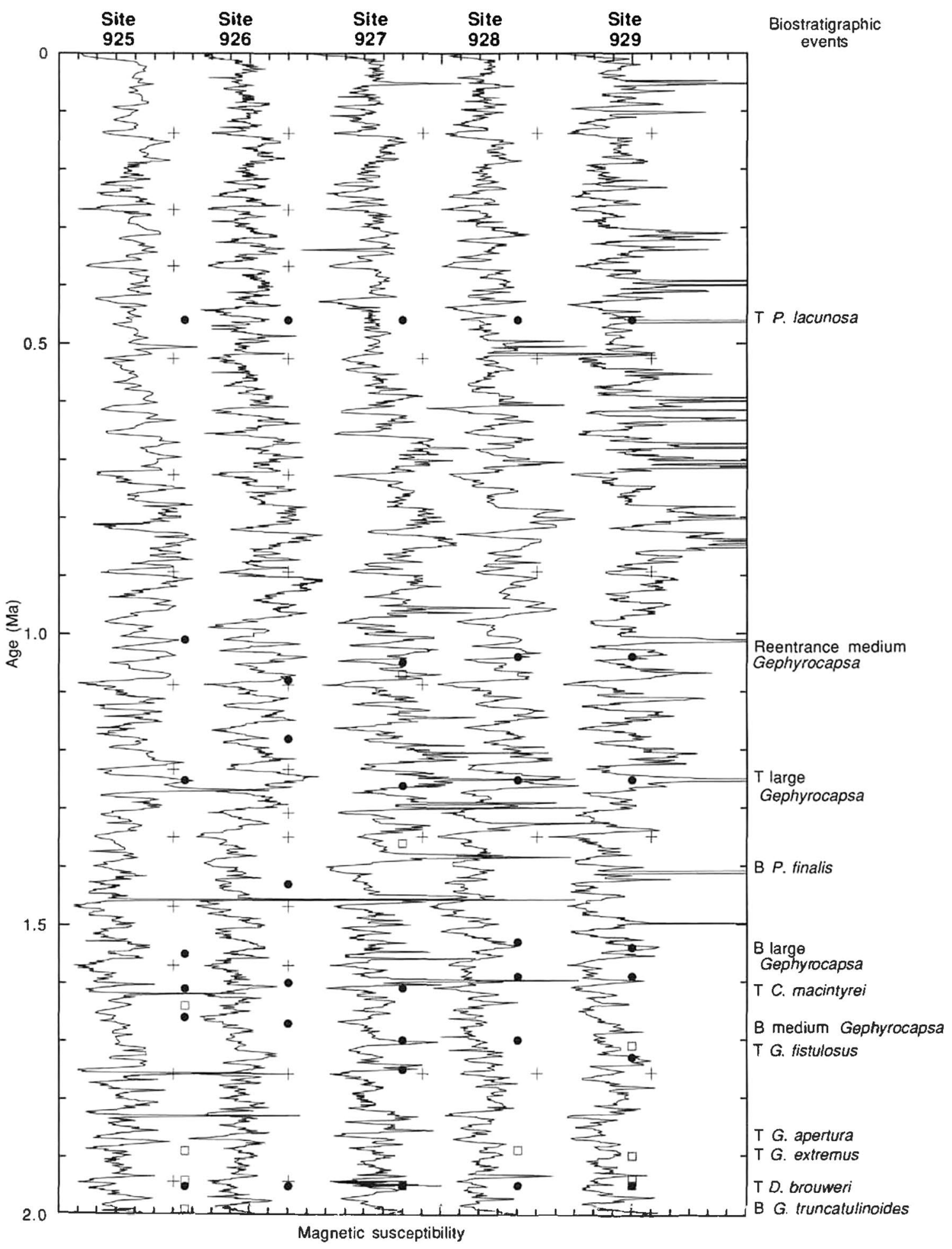

Fig. 6 Composite magnetic susceptibility records of ODP Sites 925, 926, 927, 928 and 929 vs. age for the last 2 m.y. Correlation among sites was based on the graphic correlation tie points (plus signs), and confirmed by the sequence of calcareous plankton biohorizons, listed to the left and including mostly nannofossil biohorizons (black dots). Note that the ages for the tie points were obtained from selected nannofossil events of Site 926. (Reproduction of Fig. 8 published in Shipboard Scientific Party 1995) 


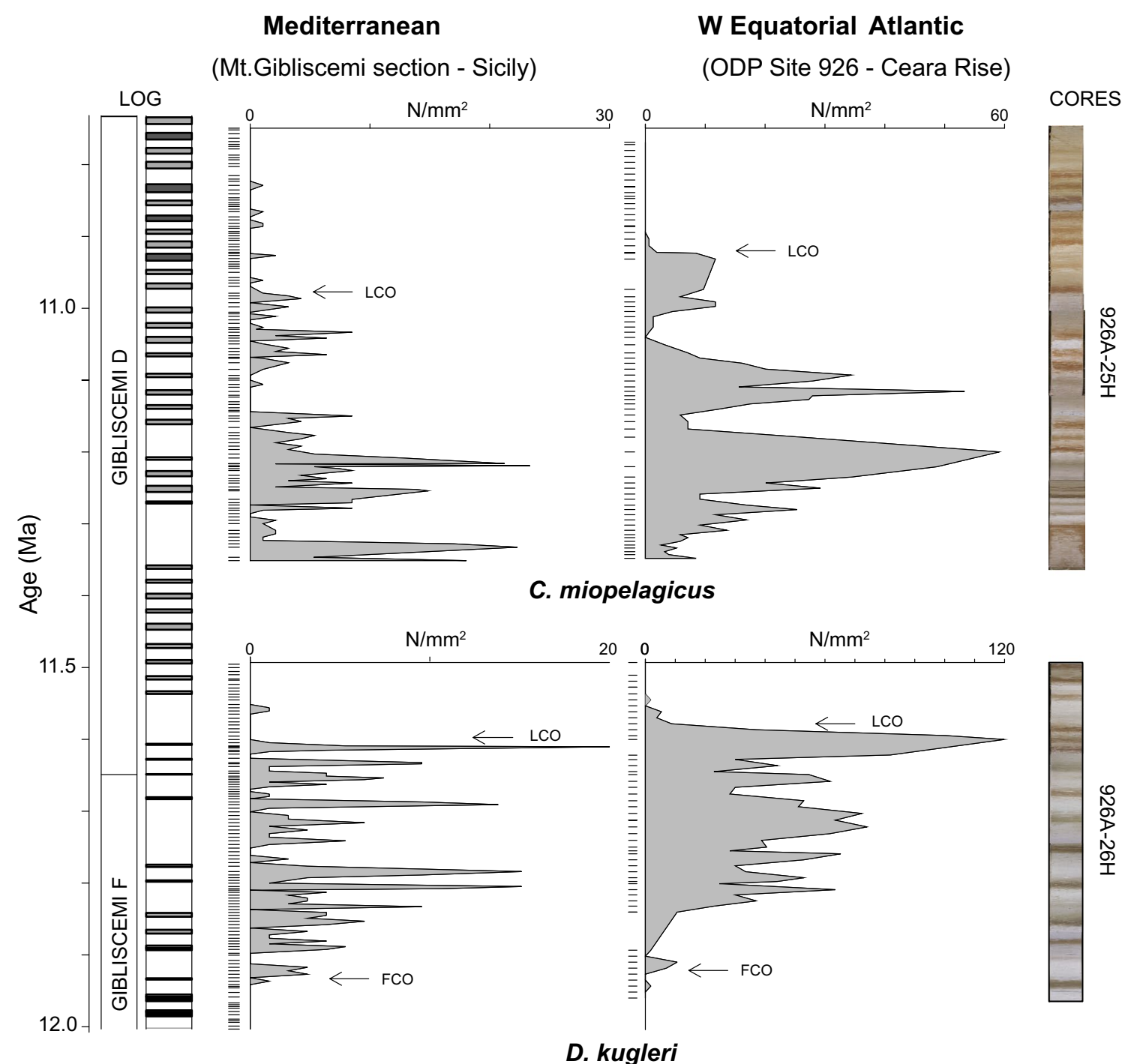

Fig. 7 Comparison of (semi)quantitative distribution patterns of Coccolithus miopelagicus and Discoaster kugleri in sedimentary sections with cyclic patterns in the equatorial Atlantic (at Ceara Rise) and in the Mediterranean (Mt. Gibliscemi). Time series based on

with each other even though resulting from two independently established astronomical timescales, by Shackleton and Crowhurst (1997) for low latitude Atlantic and by Hilgen et al. (2000) for Mediterranean. In our opinion, this correspondence expresses the mutual consistency of the two timescales (with a possible difference of only one or two precession cycles) and the indubitable biochronological value of these nannofossil biohorizons, an example among many others in the Cenozoic nannofossil biochronology.

the independently established astronomical chronologies for Ceara Rise (Shackleton and Crowhurst 1997) and Monte Gibliscemi (Hilgen et al. 2000). $\mathrm{FCO}=$ First Common/continuous Occurrence; $\mathrm{LCO}=$ Last Common/continuous Occurrence

\section{Conclusion}

The usefulness of calcareous nannofossils for stratigraphic purposes, via biostratigraphy and biochronology, and their role in the construction of age models for the Cenozoic have been highlighted during the last 6 decades through a rich literature based on studies on suitable marine sedimentary sequences, applying rigorous and detailed methods of analysis. The attributes of this microfossil group, functional to biostratigraphic classification, lead to improvement of their correlation potential and achievement of a high degree of reliability in various time-intervals in the last 66 million years. These results underline the importance of integrating high quality biostratigrahic data with the other 
high-resolution stratigraphic signals. Calcareous nannofossil biohorizons are used as control points of dating tools such as cyclostratigraphy and magnetostratigraphy, namely for the identification of cycle numbers and polarity zones and represent powerful means for regional and worldwide correlations.

Acknowledgements We thank the few pioneers who began to develop Cenozoic calcareous nannofossil biostratigraphies as well as their many followers in the marine biostratigraphic, magnetostratigraphic and cyclostratigraphic communities. We are also greatly indebted to the many colleagues and crews with which we have had the opportunity and pleasure to sail and work with during various DSDP, ODP and IODP cruises/legs/expeditions, organized and financed by the many countries that support international efforts to unravel Earth's history as preserved in deep-sea sediments. Finally, we are grateful to Giuliana Villa and an anynomous reviewer for helpful comments.

Funding Most of the data presented here resulted from our research and were based on samples provided by the Ocean Drilling Program (ODP) sponsored by the U.S. National Science Foundation (NSF) and participating countries under management of the Joint Oceanographic Institutions (JOI). Financial support was from the Università degli Studi "G. d'Annunzio" di Chieti-Pescara.

\section{Declarations}

Conflict of interest All authors certify that they have no affiliations with or involvement in any organization or entity with any financial interest or non-financial interest in the subject matter or materials discussed in this manuscript.

Ethical statement This paper has not been published elsewhere and we have no conflicts of interest to disclose. Results are presented clearly, honestly, and without inappropriate data manipulation (including image-based manipulation). No data, text, or theories by others are presented as if they were the author's own ('plagiarism').

\section{Availability of data and material Not applicable.}

Code availability Not applicable.

Open Access This article is licensed under a Creative Commons Attribution 4.0 International License, which permits use, sharing, adaptation, distribution and reproduction in any medium or format, as long as you give appropriate credit to the original author(s) and the source, provide a link to the Creative Commons licence, and indicate if changes were made. The images or other third party material in this article are included in the article's Creative Commons licence, unless indicated otherwise in a credit line to the material. If material is not included in the article's Creative Commons licence and your intended use is not permitted by statutory regulation or exceeds the permitted use, you will need to obtain permission directly from the copyright holder. To view a copy of this licence, visit http://creativecommons.org/licenses/by/4.0/.

\section{References}

Agnini C, Fornaciari E, Raffi I, Rio D, Röhl U, Westerhold T (2007) High-resolution nannofossil biochronology of middle Paleocene to early Eocene at ODP Site 1262: implications for calcareous nannoplankton evolution. Mar Micropaleont 64:215-248. https:// doi.org/10.1019/j.marmicro.2007.05.003

Agnini C, Fornaciari E, Raffi I, Catanzariti R, Pälike H, Backman J, Rio D (2014) Biozonation and biochronology of Paleogene calcareous nannofossils from low and middle latitudes. Newslett Stratigr 47:131-181. https://doi.org/10.1127/0078-0421/2014/0042

Arrhenius G (1952) Sediment cores from the East Pacific. In: Pettersson H (ed), Reports of the Swedish Deep Sea Expedition, 1947-1948, 5:1-201

Backman J (1986) Late Paleocene to middle Eocene calcareous nannofossil biochronology from the Shatsky Rise, Walvis Ridge and Italy. Palaeogeogr Palaeoclimatol Palaeoecol 57:43-59. https:// doi.org/10.1016/0031-0182(86)90005-2

Backman J, Shackleton NJ (1983) Quantitative biochronology of Pliocene and early Pleistocene calcareous nannofossils from the Atlantic, Indian and Pacific oceans. Mar Micropal 8:141-170. https://doi.org/10.1016/0377-8398(83)90009-9

Backman J, Raffi I, Rio D, Fornaciari E, Pälike H (2012) Biozonation and biochronology of Miocene through Pleistocene calcareous nannofossils from low and middle latitudes. Newslett Stratigr 45:221-244. https://doi.org/10.1127/0078-0421/2012/0022

Backman J, Pestiaux P (1987) Pliocene Discoaster abundance variations, Deep Sea Drilling Project Site 606; biochronology and paleoenvironmental implications. In: Ruddiman WF, Kidd RB, et al. (ed), Init Repts DSDP 94:903-910. https://doi.org/10.2973/ dsdp.proc.94.126.1987

Backman J, Raffi I (1997) Calibration of Miocene nannofossil events to orbitally tuned cyclostratigraphies from Ceara Rise. In: Curry WB, Shackleton NJ, Richter C, Bralower TJ (eds), Proc ODP Sci Res 154:83-99. https://doi.org/10.2973/odp.proc.sr.154.101.1997

Berggren WA (1969) Cenozoic chronostratigraphy, planktonic foraminiferal zonation and the radiometric time scale. Nature 224:1072-1075. https://doi.org/10.2307/1484931

Berggren WA, Kent DV, van Couvering JA (1985) Neogene geochronology and chronostratigraphy. In: Snelling NJ (ed) The chronology of the geological record. Geol Soc Lond Mem. 10:211-260. https://doi.org/10.1144/gsl.mem.1985.010.01.18

Berggren WA, Kent DV, Swisher CC III, Aubry M-P (1995) A revised Cenozoi geochronology and chronostratigraphy. In: Berggren WA, Kent DV, Aubry M-P, Hardenbol J (eds) Geochronology, time scales and global stratigraphic correlation: A unified temporal framework for an historical geology. Spec Publ Soc Econ Paleont Min 54:29-212. https://doi.org/10.2110/pec.95.04.0129

Bown PR, Lees JA, Young JR (2004) Calcareous nannoplankton evolution and diversity through time. In: Thierstein HR, Young JR (eds), Coccolithophores - from molecular processes to global impact. Springer, 481-508. https://doi.org/10.1007/978-3-66206278-4_18

Bown PR (1998) Triassic. In Bown PR (ed), Calcareous Nannofossil Biostratigraphy. Kluwer Acad Publ, 29-33

Bramlette MN, Riedel WR (1954) Stratigraphic value of discoasters and some other other microfossils related to Recent coccolithophores. J Paleont 28:385-403

Bramlette MN, Sullivan FR (1961) Coccolithophorids and related nannoplankton of the early Tertiary in California. Micropaleont 7:129-188. https://doi.org/10.2307/1484276

Bramlette MN, Wicoxon JA (1967) Middle Tertiary calcareous nannoplankton of the Cipero Section, Trinidad, W.I. Tulane Stud Geol 5:93-131

Bukry D (1973) Low-latitude coccolith biostratigraphic zonation. In: Edgar NT, Saunders JB (eds), Init Repts DSDP 15:685-703. https://doi.org/10.2973/dsdp.proc.15.116.1973

Cande SC, Kent DV (1992) A new geomagnetic polarity time scale for the late cretaceous and Cenozoic. J Geophys Res 97:1391713951. https://doi.org/10.1029/92jb01202 
Chepstow-Lusty A, Backman J, Shackleton NJ (1989) Comparison of upper Pliocene Discoaster abundance variations from North Atlantic sites 552, 607, 658, 659, 662; further evidence for marine plankton responding to orbital forcing. In: Ruddiman W, Sarnthein M, et al. (eds), Proc ODP Sci Res 108:121-141. https://doi.org/ 10.2973/odp.proc.sr.108.122.1989

Cox A, Doell RR, Dalrymple GB (1963) Geomagnetic polarity epochs and Pleistocene goechronometry. Nature 198:1049-1105. https:// doi.org/10.1038/1981049a0

Curry WB, Shackleton NJ, Richter C et al. (1995) Proc ODP Init Repts 154. https://doi.org/10.2973/odp.proc.ir.154.1995

Ellis CH (1979) Neogene nannoplankton in eastern Mediterranean. Ann Geol Pays Hell 1:391-401

Emiliani C (1954) Temperatures of Pacific bottom waters and polar superficial waters during the Tertiary. Science 119:853-855. https://doi.org/10.1126/science.119.3103.853

Emiliani C (1955) Pleistocene temperatures. J Geol 63:538-578. https://doi.org/10.1086/626295

Emiliani C (1966) Isotopic paleotemperatures. Science 154:851-857. https://doi.org/10.1126/science.154.3751.851

Gartner S (1992) Miocene nannofossil chronology in the North Atlantic, DSDP Site 608. Mar Micropaleont 18:307-331. https://doi. org/10.1016/0377-8398(92)900-45L

Gibbs S, Shackleton NJ, Young J (2004) Orbitally forced climate signals in mid-Pliocene nannofossil assemblages. Mar Micropaleont 51:39-56. https://doi.org/10.1016/j.marmicro.2003.09.002

Glen W (1982) The road to Jaramillo: Critical years of the revolution in Earth Science. Stanford University Press, Redwood City

Gradstein FM, Ogg JG, Schmitz MD, Ogg GM (2020) The Geologic Time Scale 2020. Elsevier BV. https://doi.org/10.1016/ C2020-1-02369-3

Gribbin J (1976) Mason develops Milankovich Ice Age theory. Nature 260:396. https://doi.org/10.1038/260396a0

Harrison CGA, Funnell BM (1964) Relationship of palæomagnetic reversals and micropælontology in two late Cænozoic cores from the Pacific Ocean. Nature 204:566. https://doi.org/10.1038/20456 $6 \mathrm{a} 0$

Hay WW, Mohler HP, Roth PH, Schmidt RR, Boudreaux JE (1967) Calcareous nannoplankton zonation of the Cenozoic of the Gulf Coast and Caribbean-Antillean area, and transoceanic correlation. Transact Gulf Coast Ass Geol Soc 7:428-467

Hays JD, Imbrie J, Shackleton NJ (1976) Variations in the Earth's orbit: pacemaker of the Ice Ages. Science 194:1121-1132. https://doi. org/10.1126/science.194.4270.1121

Heirtzler JR, Dickson GO, Herron EM, Pitman WC III, Lepichon X (1968) Marine magnetic anomalies, geomagnetic field reversals, and motions of the ocean floor and continents. J Geophys Res 73:2119-2136. https://doi.org/10.1029/JB073i006p02119

Hilgen FJ (1987) Sedimentary rhythms and high-resolution chronostratigraphic correlations in the Mediterranean Pliocene. Newsl Stratigr 17:109-127. https://doi.org/10.1127/nos/17/1987/109

Hilgen FJ (1991a) Astronomical calibration of Gauss to Matuyama sapropels in the Mediterranean and implication for the Geomagnetic Polarity Time Scale. Earth Planet Sci Lett 104:226-244. https:// doi.org/10.1016/0012-821X(91)90206-W

Hilgen FJ (1991b) Extension of the astronomically calibrated (polarity) time scale to the Miocene / Pliocene boundary. Earth Planet Sci Lett 107:349-368. https://doi.org/10.1016/0012-821X(91) 90082-S

Hilgen FJ, Krijgsman W, Raffi I, Turco E, Zachariasse WJ (2000) Integrated stratigraphy and astronomical calibration of the Serravallian/Tortonian boundary section at Monte Gibliscemi (Sicily, Italy). Mar Micropaleont 38:181-211

Huxley TH (1868) On some organisms living at great depths in the North Atlantic Ocean Quarterly. Journal of Microscopical Science v. VIII new series: 203-212.
Kidd RB, Cita MB, Ryan WBF (1978) Stratigraphy of eastern Mediterranean sapropel sequences recovered during DSDP Leg 42A and their paleoenvironmental significance. In: Hsü KJ, Montadert L, et al Init Repts DSDP 42, Part 1:421-443. https://doi.org/10.2973/ dsdp.proc.42-1.113-1.1978

Kroenke LW, Berger WH, Janecek TR et al. (1991) Proc ODP Init Repts 130. doi:https://doi.org/10.2973/odp.proc.sr.130.1993

Martini E (1971) Standard Tertiary and Quaternary calcareous nannoplankton zonation. In: Farinacci A (ed), Proc 2nd Intern Confer Planktonic Microfossils Roma 2:739-785

Ness G, Levi S, Couch R (1980) Marine magnetic anomaly timescales for the Cenozoic and Late Cretaceous: A précis, critique, and synthesis. Rev Geophys Space Phys 18:753-770

Olafsson G (1991) Late Oligocene through late Miocene calcareous nannofossil biostratigraphy and biochronology. $\mathrm{PhD}$ dissertation, Medd Stockholms Universitets Inst Geologi och Geokemi, 283

Opdyke ND, Glass B, Hays JD, Foster J (1966) Paleomagnetic study of Antarctic deep-sea cores: Paleomagnetic study of sediments in a revolutionary method of dating events in Earth's history. Science 154:349-357. https://doi.org/10.1126/science.154.3747.349

Pearson, PN (2012) Oxygen isotopes in foraminifera: Overview and historical review. In: Ivany LC, Huber BT (ed) Reconstructing Earth's deep-time climate, Paleont Soc Pap 18:1-38

Perch-Nielsen K (1985) Cenozoic calcareous nannofossils. In: Bolli HM, Saunders JB, Perch-Nielsen K (eds) Plankton stratigraphy. Cambridge Univ Press, Cambridge, pp 427-554

Raffi I (1999) Precision and accuracy of nannofossil biostratigraphic correlation. Philos Trans A Roy Soc Lond 357:1975-1993

Raffi I, Rio D (1979) Calcareous nannofossil biostratigraphy of DSDP Site 132 - Leg 13 (Tyrrhenian Sea-Western Mediterranean). Riv It Paleontol Stratigr 85:127-172

Raffi I, Backman J, Rio D, Shackleton NJ (1993) Plio-Pleistocene nannofossil biostratigraphy and calibration to oxygen isotope stratigraphies from Deep Sea Drilling Project Site 607 and Ocean Drilling Program 677. Paleoceanogr 8:387-408. https://doi.org/ 10.1029/93PA00775

Raffi I, Backman J, Fornaciari E, Pälike H, Rio D, Lourens L, Hilgen $F$ (2006) A review of calcareous nannofossil astrobiochronology encompassing the past 25 million years. Quat Sci Rev 25:31133137. https://doi.org/10.1016/j.quascirev.2006.07.007

Raffi I, Wade BS, Pälike H (2020) The Neogene Period (Chapter 29). In Geological Time Scale 2020, FM Gradstein, JG Ogg, MD Schmitz, GM Ogg (eds) Volume 2:1141-1215. https://doi.org/ 10.1016/B978-0-12-824360-2.00029-2

Raymo ME, Ruddiman WF, Backman J, Clement B, Martinson DG (1988) Late Pliocene variation in Northern Hemisphere ice sheets and North Atlantic deep water circulation. Paleoceanogr 4:413446. https://doi.org/10.1029/PA004i004p00413

Rio D, Raffi I, Villa G (1990) Pliocene - Pleistocene calcareous nannofossil distribution patterns in the Western Mediterranean. In Kastens K, Mascle J et al. (eds) Proc ODP Sci Res 107:513-533. https://doi.org/10.2973/odp.proc.sr.107.164.1990

Saito T, Burckle LH, Hays JD (1975) Late Miocene to Pleistocene biostratigraphy of equatorial Pacific sediments. In: Saito T, Burckle LH (eds) Late Neogene epoch boundaries, Micropal Spec Publ 1:226-244

von Salis K (1998) Calcareous nannofossils. Column for Triassic chart of Mesozoic and Cenozoic sequence chronostratigraphic framework of European basins. In: de Graciansky P-C, Hardenbol J, Jacquin TH, Vail PR, (eds) Mesozoic-Cenozoic Sequence Stratigraphy of European Basins, SEPM Special Publication, 60:Chart 8

Schulte $\mathrm{P}$ et al (2010) The Chicxulub asteroid impact and mass extinction at the Cretaceous-Paleogene boundary. Science 327:12141218. https://doi.org/10.1126/science. 1177265

Sepkoski JJJr (1996) Patterns of Phanerozoic extinction: a perspective from global data bases. In: Walliser $\mathrm{OH}$ (ed) Global events 
and event stratigraphy, Springer, 35-51. https://doi.org/10.1007/ 978-3-642-79634-0_4

Shackleton NJ (1967) Oxygen isotope analyses and Pleistocene temperatures re-assessed. Nature 215:15-17. https://doi.org/10.1038/ 215015A0

Shackleton NJ, Opdyke ND (1973) Oxygen isotope and palaeomagnetic stratigraphy of Equatorial Pacific Core V28-238: oxygen isotope temperatures and ice volumes on a $10^{5}$ year and $10^{6}$ year scale. Quat Res 3(39):55. https://doi.org/10.1016/033-5894(73)90052-5

Shackleton NJ, Berger A, Peltier WR (1990) An alternative astronomical calibration of the lower Pleistocene timescale based on ODP Site 677. Trans R Soc Edinburg: Earth Sci 81:251-261

Shackleton NJ, Crowhurst S 1997. Sediment fluxes based on an orbitally tuned time scale 5 ma to 14 ma, Site 926. In: Curry WB, Shackleton NJ, Richter C, Bralower TJ (eds) Proc ODP Sci Res 154:69-82. https://doi.org/10.2973/odp.proc.sr.154.102.1997

Shackleton NJ, Baldauf JG, Flores J-A, Iwai M, Moore TC Jr, Raffi I, Vincent E (1995) Biostratigraphic summary for Leg 138. In: Pisias, NG, Mayer LA, Palmer-Julson A, van Andel TH (eds) Proc ODP Sci Res 138:517-533. https://doi.org/10.2973/odp.proc.sr. 138.127.1995

Shipboard Scientific Party (1988) Site 690. In: Barker PE, Kennett J (eds) Proc ODP Init Repts 113:183-292. https://doi.org/10.2973/ odp.proc.ir.113.107.1988

Shipboard Scientific Party (1995) Leg 154 Synthesis. In: Curry WB, Shackleton NJ, Richter C (eds) Proc ODP Init Repts 154:421-442. https://doi.org/10.2973/odp.proc.ir.154.109.1995

Speijer RP, Pälike H, Hollis CJ, Hooker JJ, Ogg JG (2020) The Paleogene Period (Chapter 28). In Geological Time Scale 2020, FM Gradstein, JG Ogg, MD Schmitz, GM Ogg (eds) Volume 2: 1087-1140. https://doi.org/10.1016/B978-0-12-824360-2.00028-0

Stradner H (1961) Vorkommen von Nannofossilien im Mesozoikum und Alttertiär. Erdoel-Z 77:77-88
Stradner H (1959) First report on the discoasters of the Tertiary of Austria and their stratigraphic use. Proc 5th World Petrol Congr New York 1:1081-1095

Thierstein HR, Geitzenauer KR, Molfino B, Shackleton NJ (1977) Global synchroneity of late Quaternary coccolith datum levels: validation by oxygen isotopes. Geology 5:400-404. https://doi. org/10.1130/0091-7613(1077)5\%3c400:GSOLQC\%3e2.0.CO;2

Urey HC (1948) Oxygen isotopes in nature and in the laboratory. Science 108:489-496. https://doi.org/10.1126/science.108.2810.489

Wallich GC (1861) Remarks on some novel phases of organic life at great depths in the sea. Ann Magz Nat Hist Ser 3:52-58

Watkins DK, Raffi I (2020) Calcareous nannofossils (Subchapter 3F), Chapter 3 Evolution and Biostratigraphy. In Geological Time Scale 2020, FM Gradstein, JG Ogg, MD Schmitz, GM Ogg (eds) Volume 1: 69-73. 978-0-12-834360-2.00003-6

Westerhold T et al (2020) An astronomically dated record of Earth's climate and its predictability over the last 66 million years. Science 369:1383-1387. https://doi.org/10.1126/science.aba6853

Young JR, Bergen JA, Bown PR, Burnett JA, Fiorentino A, Jordan RW, Kleijne A, van Niel BE, Romein AJT, von Salis K (1997) Guidelines for coccolith and calcareous nannofossil terminology. Palaeontology 40:875-912

Zachos JC, Pagani M, Sloan L, Thomas E, Billups K (2001) Trends, rhythms, and aberrations in global climate $65 \mathrm{Ma}$ to present. Science 292:686-693. https://doi.org/10.1126/science.1059412

Publisher's Note Springer Nature remains neutral with regard to jurisdictional claims in published maps and institutional affiliations. 